\title{
Credit risk management A comparative study of Islamic banks and conventional banks in Pakistan
}

\author{
Hassan Akram \\ General Banking and Finance, National Bank of Pakistan, Lahore, Pakistan, and \\ Khalil ur Rahman \\ AlHuda Center of Islamic Banking and Economics, Lahore, Pakistan
}

\section{Credit risk management}

Received 9 September 2017 Revised 30 September 2017 20 January 2018 27 August 2018 19 September 2018 Accepted 19 September 2018

\begin{abstract}
Purpose - This study aims to examine and compare the credit risk management (CRM) scenario of Islamic banks (IBs) and conventional banks (CBs) in Pakistan, keeping in view the phenomenal growth of Islamic banking and its future implications.

Design/methodology/approach - A sample of five CBs and four IBs was chosen out of the whole banking industry for the study. Secondary data obtained from the banks' annual financial reports for 13 years, starting from 2004 to 2016, were analyzed. Multiple regression, correlation and descriptive analysis were used in the examination of the data.

Findings - The results show that loan quality (LQ) has a positive and significant impact on CRM for both IBs and CBs. Asset quality (AQ), on the other hand, has a negative impact on CRM in the case of IBs, but has a significantly positive relation with CRM in the case of CBs. The impact of 16 ratios measuring LQ and AQ have also been individually checked on CRM, by making use of a regression model using a dummy variable of financial crises for robust comparison among CBs and IBs. The model proved significant, and CRM performance of IBs was observed to be better than that of CBs. Moreover, the mean average value of financial ratios used as a measuring tool for these variables shows that the CRM performance of IBs operating in Pakistan was better than that of CBs over the period of the study.

Practical implications - The research findings are expected to facilitate bankers, investors, academics and policy makers to build a better understanding of CRM practices as adopted by CBs and IBs. The findings would be useful in formulating policy measures for the progress of the banking industry in Pakistan.
\end{abstract}

Originality/value - This research is unique in terms of its approach toward analyzing and comparing CRM performance of CBs and IBs. Such work has not been carried out before in the Pakistani banking industry.

Keywords Pakistan, Conventional banking, Islamic banking, Risk management, Credit risk management, Loan quality

Paper type Research paper

\section{Introduction}

Credit risk management (CRM) is one of the most important activities that banks have to undertake to survive ever-growing competition in the banking industry. The overall banking sector in Pakistan has been progressing, with a growth rate above 6 per cent in

(C) Hassan Akram and Khalil ur Rahman. Published in ISRA International Journal of Islamic Finance. Published by Emerald Publishing Limited. This article is published under the Creative Commons Attribution (CC BY 4.0) licence. Anyone may reproduce, distribute, translate and create derivative works of this article (for both commercial and non-commercial purposes), subject to full attribution to the original publication and authors. The full terms of this licence may be seen at http://creativecommons.org/licences/by/4.0/legalcode

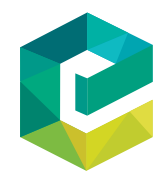

ISRA International Journal of Islamic Finance Vol. 10 No. 2,2018 pp. $185-205$
Emerald Publishing Limited Emerald Publishing Limited
0128-1976 DOI 10.1108/JJIF-09-2017-0030 
2016; it contributed 3.3 per cent to the gross domestic product (GDP) in the same year. The Islamic banking sector showed an even more robust growth of approximately 14 per cent in 2016, according to statistics from the State Bank of Pakistan. This study has been carried out to assess the CRM performance of the banking industry in Pakistan, specifically comparing CRM in Islamic banks (IBs) and conventional banks (CBs).

Credit risk is linked with the basic business operations of banks that include lending and deposit transactions. It is described as the risk of economic loss arising out of the failure of a counterparty to fulfill its contractual obligations (Jorion and GARP, 2009). It can be one of the factors responsible for bank failures. Palubinskas and Stough (1999) found that bad loans along with deficiency of banking skills, inadequate regulations and deposit insurance, mismanagement and corruption are causes of banking institution failures. An earlier study conducted by Kaplan and Stein (1993) found that high debt levels lead to the higher possibility of bankruptcy. Profitability of the bank can be increased if risk is managed efficiently (Öker, 2007).

Credit risk is generally segmented into two components: systematic and unsystematic. Systematic risk arises out of fluctuations in economic, social and political circumstances and affects all financial (capital and monetary) markets and securities (financial assets) that are traded in markets (Yurdakul, 2014). Unsystematic credit risk is subject to the characteristics of the industry in which the firm operates. It is composed of elements such as poor management, new innovations, technological developments, and changes in consumer preferences. Management, operational, financial and industrial risks are identified as unsystematic risks (Yurdakul, 2014).

This study compares CRM performance of IBs and CBs in Pakistan's banking industry and analyzes asset quality (AQ) and loan quality (LQ) exhibited by the banks for this purpose. The findings and analysis deduced from this research work are expected to enlighten policymakers on prevailing CRM issues in both IBs and CBs and enable them to develop solutions as necessary. This research also contributes towards the improvement of the banking industry's risk management practices in both IBs and CBs.

The paper is structured as follows: first, the relevant literature is reviewed and the hypothesis is constructed. Next, the research methodology and data analysis are elaborated. Finally, the conclusion is presented in the light of the research findings.

\section{Literature review}

Banks perform the role of financial intermediaries, and their main function is to convert the maturity of short-term deposits into long-term loans. This activity makes banks vulnerable to credit risk; default by counterparties or any other untoward situation can push banks into a liquidity problem. Outstanding performance of banks' credit departments and/or the credit portfolio of banks thus ensure banks' stability and help avoid default. Therefore, scrutinizing the financial history and background of the customer is a very important element before making any credit decision, and it is a vital factor in minimizing credit risk (Bekhet and Eletter, 2014). Abdul Manab et al. (2015) conducted a study to find the determinants of credit risk and analyzed the effect of earnings management with regard to credit risk prediction. Earnings management is referred to as manipulation of accounting numbers within the scope of Generally Accepted Accounting Principles. In the study by Abdul Manab et al. (2015), it was inferred that liquidity ratio was instrumental in the determination of credit risk before the aspect of earnings management was taken into account, and after it too. It was also pertinent to find that the productivity ratio was essential in the model that did not adjust for earnings management, while it was important in the model which did take into consideration earnings management. 
Credit losses can be faced by a bank due to counterparty default or due to a decline in market value arising from credit quality migration of the bank or of the counterparty (Duffie and Singleton, 1999). A credit quality migration model helps in assessing the risk of credit portfolios by estimating a portfolio value distribution for analysis (Tsaig et al., 2010). Credit risk has been segmented into the risk of loss because of changes in credit spread (gauged by the change of rating) with a market valuation of products (credit spread risk) and the risk of loss because of failure to comply with the financial obligations of the counterparty (credit default risk).

Different authors have examined the determinants of credit risk in banks. Louzis et al. (2012) analyzed the important factors of credit risk in the Greek banking system by using non-performing loans (NPL) of different loan categories as the dependent variables. They found that the NPLs of Greek banks are majorly defined by macroeconomic variables like unemployment, GDP and interest rate. Berger and DeYoung (1997), on the other hand, analyzed bank-specific variables as an indicator for the efficiency of banks and problem loans. They found that cost efficiency and capital are not positively related to problem loans. Demirgüç-Kunt and Huizinga (1999), on their part, concluded that AQ, capital adequacy, competence of management and earnings are a few of the significant explanatory variables for bank failures.

How et al. (2005) revealed that in Malaysia banks working in the Islamic financing space faced significantly less credit risk as compared with banks that do not offer Islamic financing. It was also derived that size has significant influence on the credit risk of IBs and CBs. Ahmad and Ahmad (2004) analyzed the main elements affecting credit risk of Malaysian IBs and iterated that risk-weighted assets, management efficiency and size show a significant impact on Malaysian IBs' credit risk. They also highlighted differences and similarities between credit risk determinants for CBs and IBs.

Abiola and Olausi (2014) in Nigeria used a panel regression model with return on equity (ROE) and return on asset as performance determinants, and capital adequacy ratio and (NPL) as CRM indicators. It was derived that CRM significantly impacts commercial banks' profitability in Nigeria.

\section{Credit risk management}

There are several types of risks that are faced by banks or financial institutions while operating in a competitive market. Risk is defined as an exposure where the outcome is uncertain (Knight, 1964). It is also defined as the likelihood of a loss, injury, damage, or other harmful event that occurs because of external or internal exposures that could be prevented through adoption of useful precautionary measures.

Among the important risks that banks face is credit risk. It is identified as the likelihood of a loss arising due to the borrower's inability to meet the predetermined debt obligation in the form of the principal amount along with the markup or interest charges - as per schedule (Altıntas, 2012). The development of a sound credit portfolio is only possible if useful precautionary measures are taken to mitigate credit risk.

Risk management in banking is explained as the way banks deal with risks and the related pay offs, including the identification/classification of banking risks and the methods used to measure, mitigate, monitor and control risks (Tektas et al., 2005). In today's competitive banking industry, innovation in the field of risk management can be observed in the form of modern measurements for quantifying risk (Bessis, 2011). It is an established fact that appropriate management of risk avoids deterioration of banking business. Effective and efficient management of risk has become a vital phenomenon for the success 
of banking business. The aspect of credit risk management (CRM) in banks will be elaborated in this paper.

\section{Loan quality}

Loan quality (LQ) is one of the most important variables that affect the overall credit risk of banks. Abiola and Olausi (2014) stated that low levels of liquidity and poor AQ are the two main causes of bank failures. They further found that an increasing number of banks are overextending their human resources capacity, which has caused problems such as financial crimes and poor credit appraisal, along with an increase in poor AQ. This situation is said to have increased the number of distressed banks. According to Nkusu (2011), keeping in view economic factors, LQ is also impacted by inflation, but this impact can be ambiguous and can demonstrate negative or positive relationship with the NPL portfolio.

Iannotta et al. (2007) conducted a study on 15 European countries to assess the effect of alternative ownership models, along with the degree of ownership concentration on banks' profitability. They found that private sector banks in those European countries had better LQ and lower insolvency than public sector banks. Shehzad and De Haan (2013) also found that LQ and bank capitalization are significantly affected by ownership concentration. Kopecky and VanHoose (2006), on the other hand, revealed that regulators can contribute to improving LQ by upgrading the capital requirements of banks operating in their jurisdictions. Diamond (1991) derived the existence of a positive relationship between the movement in the overall LQ and the loan rate.

Love and Ariss (2014) found that an increase in GDP and growth in capital inflows led to improvements in banks' loan portfolio quality; on the other hand, high lending rates generate adverse selection problems, and portfolio quality will go down, thus increasing credit risk. The theoretical explanation shows that LQ plays a major part in credit risk and should be taken into account when making CRM policies.

\section{Asset quality}

$\mathrm{AQ}$ is also among the vital variables that affect the credit risk of banks. The capital adequacy, $\mathrm{AQ}$, management quality, earnings and liquidity (CAMEL) model, which includes the element of AQ, has been extensively used for determining bank profitability. AQ has always played a crucial role in overall bank performance and has been an important factor in determining credit and liquidity risks in banks in different countries. Saif-Alyousf et al. (2017) determined that the CAMEL factors affected the profitability of Saudi banks. In particular, low AQ increases NPL, thus reducing banks' profitability. They also found that Saudi domestic banks were performing better than foreign banks during the period of their study. Ongore and Kusa (2013) also deployed the CAMEL model to derive that the profitability of Kenyan banks is significantly related to capital adequacy, $\mathrm{AQ}$ and management efficiency, whereas the relationship is not significant with respect to ownership.

Deteriorating AQ and the factors affecting it were elaborated by Alhassan et al. (2014) while analyzing Ghanaian banks. They identified factors like NPL in addition to loan growth, bank market structure, inflation, bank size, real exchange rate and GDP growth as significant determinants of banks' AQ. As elaborated by the authors, the assets of Ghanaian banks included:

- loans and advances;

- assets held in foreign currencies;

- investment in government securities; and

- other assets. 
The authors clearly identified that banks' assets not only included loans but other types of assets as well. It is, however, pertinent to mention that a large amount of assets (40 per cent) in Ghanaian banks consisted of loans and advances.

Therefore, it is clearly differentiated that loans and their quality (LQ) are a subset of overall $\mathrm{AQ}$, which includes other assets as well. Banks in Pakistan have almost identical structures in terms of their assets, which generally include cash and balances with treasury banks, balances with other banks, lending to financial institutions, net investments, net advances, operating fixed assets, deferred tax assets and other assets.

Doğan (2013) conducted a study to compare the financial performance of foreign and domestic banks in Turkey. By deploying financial ratios, they found that total assets, ROE, management effectiveness and AQ of local Turkish banks were better than foreign banks. The importance of $\mathrm{AQ}$ can also be determined from the research works conducted by Agoraki et al. (2011) and Gaganis et al. (2006), in which it was derived that AQ, market structure and capitalization are indicators that are more informative of banking risk than profitability, efficiency, and management qualities. From the abovementioned theoretical inferences, it can be derived that AQ is very important in terms of overall credit portfolio and CRM.

\section{Research hypotheses and methodology}

This research's main objective is to make comparative CRM analysis of CBs and IBs in Pakistan over the period 2004 to 2016. The following research hypotheses have been developed in this regard:

H1. The performance of CBs is better in comparison with IBs regarding their CRM practices.

H2. A positive relationship exists between the banks' $\mathrm{LQ}, \mathrm{AQ}$ and CRM when comparing IBs and CBs in Pakistan.

The data used have been obtained from the annual financial statements of the banks under study, which include the last 13 years of data, from 2004 to 2016. The sample (as listed in Table I) consisted of five CBs and four IBs that are considered among the largest banks in both sectors and are the pioneers of the banking industry in Pakistan.

Both of the abovementioned research hypotheses were tested using descriptive analysis, correlation and regression analysis. The independent variables (LQ and AQ) were measured using eight ratios for each variable. Following the study of Abdel Megeid (2017), the average ratio values were used for $\mathrm{AQ}$ and $\mathrm{LQ}$ measurement. The use of a dummy variable to account for the 2008 financial crisis was used for robust comparison among IBs and CBs.

\begin{tabular}{llcll}
\hline & CBs & & IBs & \\
No. & Bank name & No. & Bank name & \\
\hline 1 & Allied Bank Limited & 1 & Meezan Bank Limited & \\
2 & Habib Bank Limited & 2 & Al-Barka Bank Limited & \\
3 & Al-Falah Bank Limited & 3 & Dubai Islamic Bank Limited & Table I. \\
4 & United Bank Limited & 4 & Bank Islami Pakistan Limited & List of selected banks \\
5 & MCB Bank Limited & & & \\
\hline
\end{tabular}

Credit risk management

189

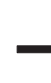


IJIF

10,2

Moreover, the following regression model was developed to depict the relationship between the independent variables $\mathrm{LQ}$ and $\mathrm{AQ}$ and the dependent variable CRM:

$$
\mathrm{CRM}=\alpha+\mathrm{LQ} \beta_{1}+\mathrm{AQ} \beta 3+\varepsilon
$$

where:

$$
\begin{aligned}
\mathrm{CRM} & =\text { credit risk management; } \\
\mathrm{LQ} & =\text { bank loan quality; } \\
\mathrm{AQ} & =\text { bank asset quality; and } \\
\varepsilon & =\text { estimation error. }
\end{aligned}
$$

All of the above-referred variables have been defined and measured using specific financial ratios, the details of which are given hereunder.

\section{Measurement of independent variables Bank loan quality}

The banks' $L Q$ has been measured by using the following ratios. Individual ratio values as well as their averages have been used in this model.

- Growth of total assets (E1): The growth of a bank's total assets can be observed on the basis of quarterly/half-yearly/yearly growth patterns, keeping in view the overall asset-liability mix, off-balance-sheet volumes and the economic environment (economic cycle) in which the bank functions. Fast-growing assets are a sign of overextension. Moreover, economic cycle phases like boom and depression must also be taken into account while assessing growth of assets and their quality (economic situation).

- Growth of gross loans (E2): Gross loan growth is a source of enhancement of a bank's interest-based earnings. Rapid growth patterns show that either the bank has targeted new markets or the economy has flourished to achieve economic boom reflected in enhanced loan-growth patterns for all banks. The reason may be that the bank has been able to acquire low-cost capital and funding that has allowed the bank to offer lower-priced (low interest) loans to borrowers. It has always been difficult to assess the quality of the borrowers that banks have been serving.

- NPLs (impaired loans)/gross loans (E3): NPLs are called impaired loans, which are overdue by more than 90 days or three months. Under the prudential regulations of the State Bank of Pakistan, banks have to classify NPL on subjective and objective bases generally into the following categories: substandard (90 days), doubtful (180 days) and loss (365 days). This ratio depicts the proportion of NPL to the gross loans of the bank. As the ratio increases, it shows lower quality of loans and poor selection of borrowers.

- Reserve for NPL/gross loans (E4): NPL reserve includes all types of provisioning for different categories of default loans. It shows the proportion among gross loans and NPL reserve amounts. An increased amount of NPL reserve or increased NPL provisioning shows a declining trend in the bank's LQ.

- Reserve for NPL (impaired loans)/impaired loans (E5): This ratio compares the reserve for NPL to total NPL loans, depicting how much reserve had to be kept by the bank as compared with total impaired loans volume. As the reserve amount increases, it is a sign of deteriorating LQ.

- Impaired loans less Reserve for impaired loans/Equity (E6): This ratio shows the relationship between NPL volume (excluding NPL reserve) and the bank's equity 
(which may include common or preferred or treasury stocks, and retained earnings, among others). It depicts how much of the percentage of equity is the NPL amount, excluding the reserve already maintained for NPL or bad loans. An increase in this ratio shows a deteriorating $\mathrm{LQ}$.

- Loan impairment charges/average gross loans (E7): Deteriorating LQ also has an impact on the income statement of the bank because this ratio shows the magnitude of the impairment charges that have been imposed on a bank's income as compared with average gross loans.

- Net charge-off/average gross loans (E8): The net charge-off includes the amount of gross loans charged off in terms of bad debt expense less the recoveries made to a similar charge-off belonging to the previous period. The recoveries in NPL reduce the previous bad debt expense provisions and give a net-charge off figure. A reduction in net charge-off shows improving conditions of a bank's LQ.

\section{Bank asset quality}

The banks' AQ has been measured by using the following ratios. The average of these eight ratios was utilized to measure the $\mathrm{AQ}$, and individual ratio values were used in the model:

- Loan loss reserve/gross loans (E9): It is the reserve for losses depicted as a percentage of gross loans. As the reserve amount increases, the quality of gross loans portfolio will show a deterioration.

- Loan loss provision/net interest revenue (E10): This ratio compares the amount of loan loss provision for bad/default loans (which is set apart as an expense) with net interest revenue presented in the profit and loss statement of the bank. A lower ratio shows a strong AQ maintenance policy of the bank.

- Loan loss reserve/impaired loans (E11): The loan loss reserve is a contra asset account subtracted/netted from the gross loan figure on a bank's asset side in its balance sheet. In this regard, a bank will be more satisfied with a higher ratio.

- Impaired loans/Gross loans (E12): This ratio compares NPL to total loans. A lower ratio is better as a lower level of impaired loans or higher level of performing gross loans are both useful.

- Net charge-off/average gross loans (E13): As already stated, loan loss reserve is a contra asset account subtracted/netted from the gross loan figure on a bank's asset side of the balance sheet. The bank will be more satisfied with a higher ratio in this regard.

- Net charge-off/net income before loan loss provision (E14): The net income figure is generated after netting off all types of expenses and charges in the income/profit and loss statement. This ratio is the relationship between net charge-off and net income before deducting/netting off loan loss provision. A lower ratio serves the bank's purpose well.

- Impaired loans/equity (E15): The ratio shows the relationship of NPL to the equity of the bank. The lower the ratio, the better the bank's AQ management.

- Unreserved impaired loans/equity (E16): This ratio depicts the relationship between impaired loans for which a reserve has not yet been kept and the bank's equity. A lower ratio serves the bank in a better manner. 
The dependent variable in this model is the banks' CRM, which has been measured by the ratio given in the following text. Loan charge-offs for the current period are first deducted from loan recoveries for the current period. The amount obtained is then divided by the previous period's loan loss allowance. The overall balance obtained will help identify the recoveries in NPL, the addition/reduction in NPL or defaulted credit portfolio and subsequent necessary provisioning:

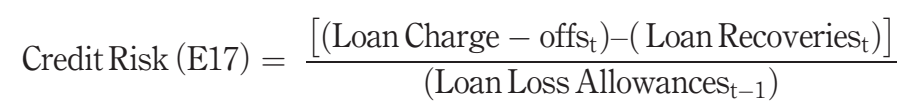

\section{Analysis and discussion}

As mentioned earlier, correlation and descriptive and regression analysis were carried out to analyze the data in this research. The ratios pertaining to the independent variables LQ and $\mathrm{AQ}$ and the dependent variable $\mathrm{CRM}$ have been compared among the sampled $\mathrm{CBs}$ and IBs. The ratios have been calculated based on the annual financial statement figures. The regression and descriptive analysis have been carried out on the basis of individual ratios, as well as their average values. For robust comparison of Islamic and conventional banking, a dummy variable to account for the 2008 financial crisis was introduced. The regression and descriptive analysis results were thus calculated before and after the 2008 financial crisis on the basis of individual ratios to further support the research model. Finally, the descriptive correlation and regression analysis were further used to see the impact of independent variables on the basis of average values of ratios to test the hypotheses. The following is a detailed analysis and discussion of results regarding the above-referred tools used to test the hypotheses.

Correlation analysis The concept of correlation is used to find out the direction of the relationship between variables and their movement accordingly. The correlation value varies between +1 and -1 :

- A correlation value of 1 means that variables are highly correlated and their movement is in the same direction.

- A correlation value of -1 , on the other hand, means that variables are highly correlated but move in opposite directions.

- A correlation value of 0 shows indifferent behavior of variables or no correlation at all.

- The correlation coefficients also depict that the problem of multicollinearity is absent.

The correlation matrix relating to the explanatory variables examined in this study is given in Tables II to V for CBs and IBs, respectively. Tables II and III depict individual and average ratio correlation results in the case of CBs. The correlation values in Table II have been obtained using 16 different ratios measuring the independent variables AQ and LQ. Eight ratios measuring the independent variables show a negative correlation with the dependent variable, whereas the rest show a positive correlation. On the other hand, Table III depicts the average values of the ratios measuring the independent variables and their correlation with the dependent variable. It can be seen that one of the independent variables in the model, notably $\mathrm{AQ}$, shows a negative correlation with the dependent variable, whereas the other independent variable, LQ, shows a positive correlation with CRM. Furthermore, the correlation coefficient values show that a problem of multicollinearity does not exist. 


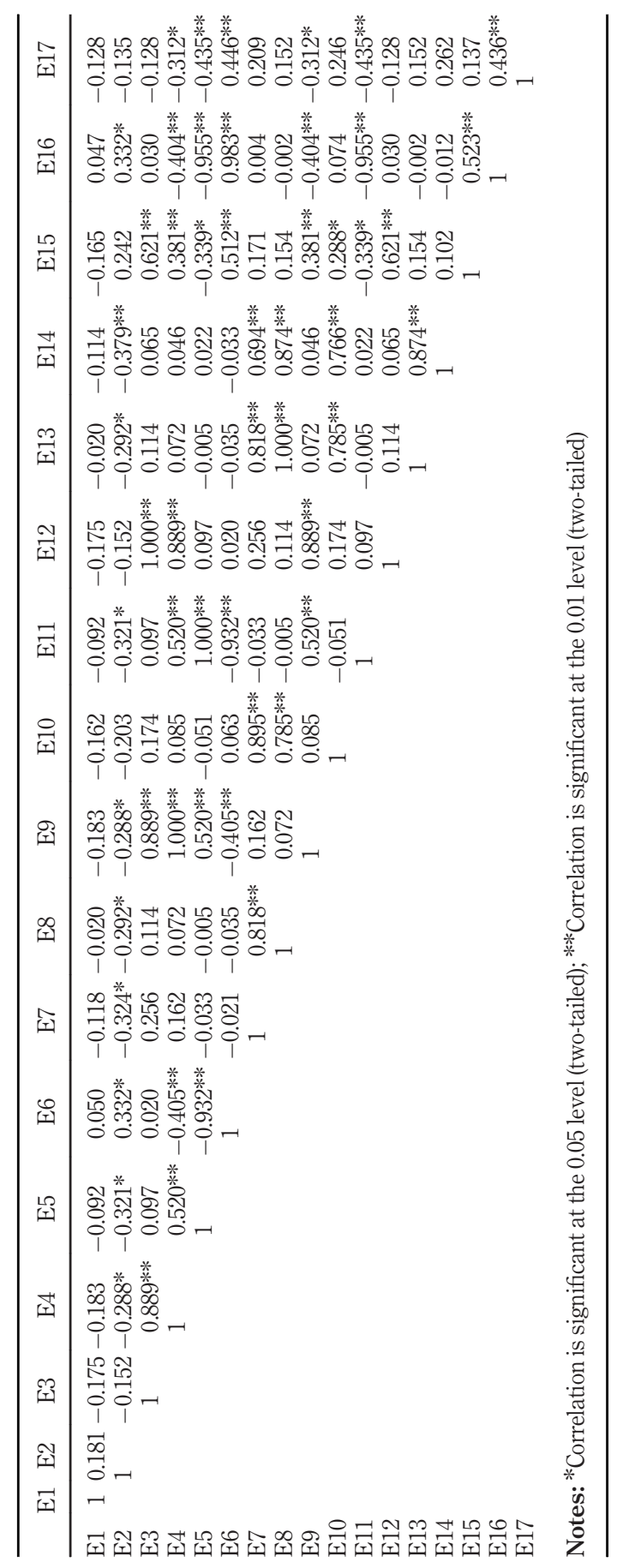

Credit risk management 
$\mathrm{IJIF}$

10,2

194

Tables IV and V present the individual and average ratio correlation results in the case of IBs. The correlation values in Table IV have been obtained using 16 different ratios measuring the independent variables AQ and LQ. Twelve ratios measuring the independent variables show a negative correlation with the dependent variable, whereas the rest show a positive correlation. On the other hand, Table V depicts the average values of the ratios measuring the independent variables and their correlation with the dependent variable. Similar to the case of $\mathrm{CBs}$, it can be seen that one of the independent variables in the model, namely, $\mathrm{AQ}$, shows a negative correlation with the dependent variable, whereas the other independent variable, LQ, shows a positive correlation with CRM. Furthermore, the correlation coefficient values also show that the problem of multicollinearity does not exist in IBs.

Descriptive analysis The descriptive analysis is shown in Tables VI to XI. The results helped in determining the performance of CBs in comparison with IBs for the period under study (2004 to 2016) and also for the periods 2004 to 2008 (before crisis) and 2009 to 2016 (after crisis) when a dummy variable was used to account for the 2008 financial crisis. The independent sample $t$ test ( $\phi$ values) has also been used to get significant variations among the obtained results. The ratios for LQ, AQ and CRM have been compared between CBs and IBs.

In Table VI, individual ratios measuring LQ and their mean values have been compared for the period 2004 to 2008 (pre-crisis). It is observed that IBs showed a better performance than CBs before the 2008 financial crisis. Similarly, Table VII shows the individual ratios measuring LQ and a comparison of their mean values for the period 2009 to 2016 (post-crisis). It is again observed that IBs show a better performance than CBs even after the 2008 financial crisis.

Table VIII presents the individual ratios measuring $\mathrm{AQ}$, and their mean values have been compared. It is found that CBs showed a better performance than IBs before the 2008 financial crisis. Similarly, Table IX shows the individual ratios measuring $A Q$, and their mean values have been compared. Again, CBs show a better performance than IBs. Nonetheless, it is pertinent to mention that the performance margin among both types of banks has been significantly reduced from 8 per cent pre-crisis to 2 per cent post-crisis. This shows that IBs have significantly improved their AQ in comparison with CBs.

Finally, Table $\mathrm{X}$ shows the descriptive analysis of the dependent variable CRM before the 2008 financial crisis. Based on the results in the table, it can be deduced that IBs are performing better in terms of CRM. Based on Table XI, which shows the performance comparison after the 2008 financial crisis, CBs have surpassed the performance of IBs.

Table XII shows the descriptive analysis of variable LQ, depicting the comparison between IBs and CBs in terms of independent variable LQ for the period 2004 to 2016. The prime earning source for banks is the interest-based loan portfolio, which is developed out of the deposit base. Banks successfully convert short-term and long-term deposits into shortterm and long-term loans. Generally, long-term loans involve more risks; therefore, they are highly priced and represent a solid source of earnings for banks. Table XII shows that the average mean of LQ for IBs was 0.199, which is much better than CBs' LQ average mean value of 0.173 for the overall 13 years' performance. This was also found to be the case when

Table III. Pearson correlations CBs

\begin{tabular}{lllc}
\hline & AQ & LQ & Credit risk \\
\hline AQ & 1 & 0.136 & -0.252 \\
LQ & & 1 & $0.360^{* *}$ \\
Credit risk & & 1 \\
Note: $* *$ Correlation is significant at the 0.01 level (two-tailed) & & \\
\hline
\end{tabular}




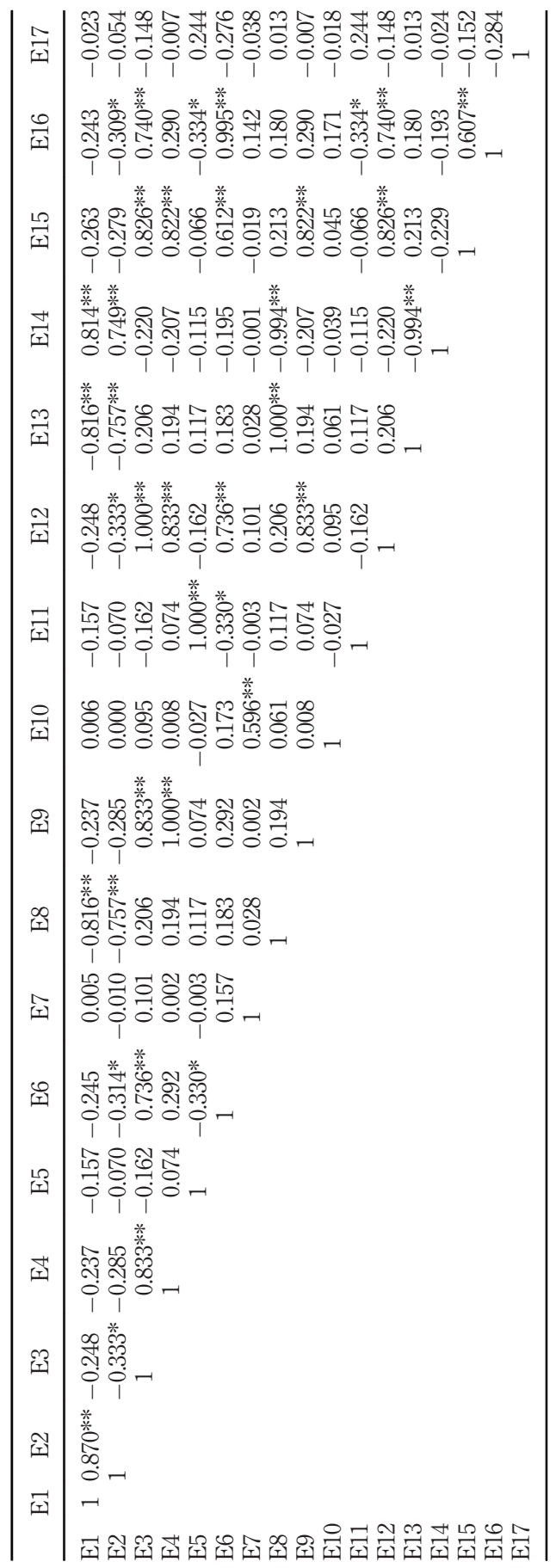


$\mathrm{IJIF}$

10,2

196

LQ performance was compared using the dummy variable for "before" and "after" the 2008 financial crisis period.

There can be numerous reasons for better LQ in IBs, such as selection of appropriate borrowers and industries when disbursing loans. Islamic banking is asset-backed and noninterest-based, targeting borrowers who believe in Islamic banking practices and financing products like mudārabah (profit sharing), mushārakah (profit-and-loss sharing) and murābahah (cost plus profit). It is pertinent to mention that it is difficult for external investors to assess the quality of borrowers that the banks are targeting or serving with their investments/deposits. The results also highlight that CBs should adopt a strategy to reduce NPL and impaired loan reserves and develop healthy loan portfolios.

\begin{tabular}{lllc}
\hline & AQ & LQ & Credit risk \\
\hline AQ & 1 & 0.011 & -0.030 \\
LQ & & 1 & $0.796^{* *}$ \\
Credit risk & & 1 \\
Note: **Correlation is significant at the 0.01 level (two-tailed) & & \\
\hline
\end{tabular}

Table V.

Pearson

Correlations - IBs

\begin{tabular}{|c|c|c|c|c|c|c|}
\hline \multirow[b]{2}{*}{ Variables } & \multicolumn{2}{|c|}{ Conventional } & \multicolumn{2}{|c|}{ Islamic } & \multirow[b]{2}{*}{ Mean difference } & \multirow[b]{2}{*}{ p-value } \\
\hline & $\mathrm{M}$ & $S D$ & $\mathrm{M}$ & $S D$ & & \\
\hline E1 & 0.1723 & 0.07593 & 0.4500 & 0.23290 & 0.278 & 0.000 \\
\hline E2 & 0.2062 & 0.12316 & 0.4636 & 0.16473 & 0.257 & 0.000 \\
\hline E3 & 0.0687 & 0.03171 & 0.0177 & 0.01317 & $(0.051)$ & 0.000 \\
\hline E4 & 0.0653 & 0.05561 & 0.0123 & 0.00671 & $(0.053)$ & 0.001 \\
\hline E5 & 0.6690 & 0.28030 & 0.8641 & 0.29594 & 0.195 & 0.058 \\
\hline E6 & 0.2536 & 0.25440 & 0.0202 & 0.06585 & $(0.233)$ & 0.001 \\
\hline E7 & 0.0309 & 0.03263 & 0.0109 & 0.00852 & $(0.020)$ & 0.021 \\
\hline E8 & 0.0369 & 0.07723 & 0.0174 & 0.18051 & $(0.020)$ & 0.692 \\
\hline Average & 0.188 & & 0.232 & & 0.04 & $*$ \\
\hline
\end{tabular}

Table VII.

Descriptive analysis of CBs vs IBs - LQ (after crisis)

\begin{tabular}{lcccccr}
\hline \multicolumn{2}{c}{ Conventional } & \multicolumn{2}{c}{ Islamic } & & \\
Variables & $\mathrm{M}$ & $\mathrm{SD}$ & $\mathrm{M}$ & $\mathrm{SD}$ & Mean difference & p-value \\
\hline E1 & 0.1446 & 0.07309 & 0.5828 & 1.92880 & 0.438 & 0.208 \\
$\mathrm{E} 2$ & 0.0564 & 0.07936 & 0.3217 & 0.31927 & 0.265 & 0.000 \\
$\mathrm{E} 3$ & 0.0935 & 0.02523 & 0.0698 & 0.05036 & $(0.024)$ & 0.021 \\
$\mathrm{E} 4$ & 0.0728 & 0.02668 & 0.0431 & 0.03136 & $(0.030)$ & 0.000 \\
E5 & 0.7889 & 0.20167 & 0.6716 & 0.28647 & $(0.117)$ & 0.060 \\
E6 & 0.1331 & 0.18363 & 0.1475 & 0.15187 & 0.014 & 0.726 \\
E7 & 0.0105 & 0.00832 & 0.0057 & 0.01077 & $(0.005)$ & 0.049 \\
E8 & 0.0017 & 0.00838 & -0.0008 & 0.01388 & $(0.002)$ & 0.384 \\
Average & 0.163 & & 0.230 & & 0.07 & $*$
\end{tabular}

Note: *IBs perform better in terms of LQ 
Table XIII presents the average mean values for the ratios measuring $\mathrm{AQ}$, showing overall performance comparison. It is evident from the results that IBs' average mean values (2.565) show better AQ ratio results than CBs' values (0.250). When LQ performance comparison was made using dummy variable for "before" and "after" the 2008 financial crisis period, the performance of CBs was found to be better than IBs. However, the difference was significantly reduced by 6 per cent, depicting extraordinary improvement of IBs after the 2008 financial crisis. This improvement heavily contributes to overall average performance of IBs.

\begin{tabular}{lcccccr}
\hline \multicolumn{2}{c}{ Conventional } & \multicolumn{2}{c}{ Islamic } & & \\
Variables & $\mathrm{M}$ & $\mathrm{SD}$ & $\mathrm{M}$ & $\mathrm{S} D$ & Mean difference & $p$-value \\
\hline E9 & 0.0461 & 0.03033 & 0.0125 & 0.00665 & $(0.034)$ & 0.000 \\
E10 & 0.2017 & 0.19525 & 0.1770 & 0.24330 & $(0.025)$ & 0.748 \\
E11 & 0.6667 & 0.28101 & 0.7589 & 0.34033 & 0.092 & 0.399 \\
E12 & 0.0854 & 0.05130 & 0.0170 & 0.01304 & $(0.068)$ & 0.000 \\
E13 & 0.0051 & 0.00657 & 0.1465 & 0.34780 & 0.141 & 0.125 \\
E14 & 0.1555 & 0.13097 & 0.2467 & 0.36148 & 0.091 & 0.352 \\
E15 & 0.6705 & 0.29065 & 0.0819 & 0.07831 & $(0.589)$ & 0.000 \\
E16 & 0.2554 & 0.25348 & 0.0132 & 0.06619 & $(0.242)$ & 0.001 \\
Average & 0.261 & & 0.182 & & $(0.08)$ & $* *$
\end{tabular}

Note: ${ }^{* * *} \mathrm{CBs}$ perform better in terms of $\mathrm{AQ}$
Credit risk management

197

Table VIII.

Descriptive analysis of CBs vs IBs - AQ (before crisis)

\begin{tabular}{lcccccr}
\hline \multicolumn{2}{c}{ Conventional } & \multicolumn{2}{c}{ Islamic } & & \\
Variables & $\mathrm{M}$ & $\mathrm{SD}$ & $\mathrm{M}$ & $\mathrm{SD}$ & Mean difference & $p$-value \\
\hline E9 & 0.0728 & 0.02668 & 0.0431 & 0.03136 & $(0.030)$ & 0.000 \\
E10 & 0.1069 & 0.08898 & 0.0992 & 0.28765 & $(0.008)$ & 0.884 \\
E11 & 0.7889 & 0.20167 & 0.6716 & 0.28647 & $(0.117)$ & 0.060 \\
E12 & 0.0935 & 0.02523 & 0.0698 & 0.05036 & $(0.024)$ & 0.021 \\
E13 & 0.0017 & 0.00838 & -0.0008 & 0.01388 & $(0.002)$ & 0.384 \\
E14 & 0.0323 & 0.15285 & 0.0938 & 1.10741 & 0.061 & 0.758 \\
E15 & 0.5232 & 0.16844 & 0.4548 & 0.34106 & $(0.068)$ & 0.310 \\
E16 & 0.1331 & 0.18363 & 0.1475 & 0.15187 & 0.014 & 0.726 \\
Average & 0.219 & & 0.197 & & $(0.02)$ & $* *$
\end{tabular}

Note: ${ }^{* * *} \mathrm{CBs}$ perform better in terms of $\mathrm{AQ}$

Table IX.

Descriptive analysis of CBs vs IBs - AQ (after crisis)

\begin{tabular}{lcccccc}
\hline & \multicolumn{2}{c}{ Conventional } & \multicolumn{2}{c}{ Islamic } & & \\
Variables & $\mathrm{M}$ & $\mathrm{SD}$ & $\mathrm{M}$ & $\mathrm{SD}$ & Mean difference & p-value \\
\hline E17 & 0.3046 & 0.33777 & 0.9297 & 0.59582 & 0.625 & 0.001 \\
Average & 0.305 & & 0.930 & & 0.625 & $* * *$ \\
Grand Average & 0.229 & & 0.249 & & 0.020 & $* * * * *$
\end{tabular}

Notes: ${ }^{* * * *}$ IBs perform slightly better in terms of credit risk; ***** On average, IBs in Pakistan perform better than CBs before financial crisis

Table X.

Descriptive analysis of CBs vs IBs - credit risk management (before crisis) 
$\mathrm{IJIF}$

10,2

198

Gross loans are a dominant part of a bank's assets, and loan portfolio quality and credit management policy play a vital role in enhancing AQ of the bank. Interbank assets or placements are also a vital part of a bank's assets. To improve the situation, the CBs should devise a strategy to reduce loan loss reserves and impaired loans and to enhance recoveries of previous NPL. This also depicts that IBs' better AQ will support them through any adverse changes in market conditions or during a liquidity crunch. It is also recommended that CBs should use interbank borrowing funds very carefully in case of heavy withdrawals by depositors, and these borrowed funds should not be used for low cost/low interest loans for aggressive increase in their asset portfolio, which could ultimately expose them to credit risk.

\section{Table XI.}

Descriptive analysis of CBs vs IBs - credit risk management (after crisis)

\begin{tabular}{lcccccr}
\hline \multicolumn{2}{c}{ Conventional } & \multicolumn{2}{c}{ Islamic } & & \\
Variables & $\mathrm{M}$ & $\mathrm{SD}$ & $\mathrm{M}$ & $\mathrm{SD}$ & Mean difference & p-value \\
\hline E17 & 0.3766 & 0.85921 & 0.2120 & 0.47382 & $(0.165)$ & 0.331 \\
Average & 0.377 & & 0.212 & & -0.165 & $* * *$ \\
Grand Average & 0.202 & & 0.214 & & 0.012 & $* * * * *$
\end{tabular}

Notes: ${ }^{* * * *} \mathrm{CBs}$ perform slightly better in terms of credit risk; ***** On average, IBs in Pakistan perform better than CBs after financial crisis

\begin{tabular}{lcccccr}
\hline \multicolumn{2}{c}{ Conventional } & \multicolumn{2}{c}{ Islamic } & & \\
Variables & $\mathrm{M}$ & $S D$ & $\mathrm{M}$ & $S D$ & Mean difference & p-value \\
\hline E1 & 0.148 & 0.070 & 0.394 & 0.533 & 0.420 & 0.097 \\
E2 & 0.111 & 0.121 & 0.401 & 0.461 & 0.227 & 0.000 \\
E3 & 0.097 & 0.039 & 0.064 & 0.054 & 0.029 & 0.000 \\
E4 & 0.075 & 0.038 & 0.035 & 0.033 & 0.026 & 0.000 \\
E5 & 0.769 & 0.220 & 0.653 & 0.635 & 0.007 & 0.818 \\
E6 & 0.166 & 0.199 & 0.159 & 0.142 & 0.066 & 0.059 \\
E7 & 0.013 & 0.011 & 0.006 & 0.011 & 0.004 & 0.004 \\
E8 & 0.003 & 0.008 & $(0.122)$ & 0.593 & 0.015 & 0.607 \\
Average & 0.173 & & 0.199 & & 0.03 & $*$
\end{tabular}

Table XII.

Descriptive analysis of CBs vs IBs - LQ

Note: *IBs perform better in terms of LQ

\begin{tabular}{lcccccr}
\hline \multicolumn{2}{c}{ Conventional } & \multicolumn{2}{c}{ Islamic } & & \\
Variables & $\mathrm{M}$ & $\mathrm{SD}$ & $\mathrm{M}$ & $\mathrm{SD}$ & Mean difference & p-value \\
\hline E9 & 0.075 & 0.038 & 0.035 & 0.033 & 0.026 & 0.000 \\
E10 & 0.185 & 0.331 & 0.125 & 0.330 & 0.048 & 0.751 \\
E11 & 0.769 & 0.220 & 0.653 & 0.635 & 0.007 & 0.395 \\
E12 & 0.097 & 0.039 & 0.064 & 0.054 & 0.029 & 0.000 \\
E13 & 0.003 & 0.008 & $(0.122)$ & 0.593 & 0.015 & 0.139 \\
E14 & 0.073 & 0.178 & 19.209 & 105.265 & 0.753 & 0.604 \\
E15 & 0.634 & 0.259 & 0.397 & 0.382 & 0.219 & 0.000 \\
E16 & 0.164 & 0.198 & 0.159 & 0.142 & 0.074 & 0.050 \\
Averages & 0.250 & & 2.565 & & 2.31 & $*$ **
\end{tabular}

Table XIII.

Descriptive analysis of CBs vs IBs - asset quality

Note: ***Islamic Banking performs better in terms of Asset Quality 
Table XIV presents the average mean values for the ratios measuring CRM. The results show that CBs are slightly better (0.490) in CRM than IBs (0.466) in terms of overall performance comparison over the 13 years. It can be inferred from the average overall descriptive results that IBs have better CRM performance (1.328) than CBs (0.228) over the 13-year period. It is pertinent to also mention that the IBs performed better than the CBs over the overall 13-year period, as well as over the period pre- and post-financial crisis. This shows that the IBs in Pakistan have a better policy for credit management and are more equipped to meet adverse conditions regarding their credit portfolios than the CBs. The CBs should try to improve their AQ and LQ, and reduce NPL. Moreover, the loan-to-deposit ratio should be maintained to avoid a liquidity crunch. The overall average of all mean averages for all three variables (LQ, AQ and CRM) shows that the IBs were performing better than the CBs. It also means that IBs' CRM is better than that of CBs.

Regression analysis Tables XV and XVI show the regression model results for CBs before and after the 2008 financial crisis, respectively. The regression analysis has been run using individual ratios, which collectively construct the independent variables LQ (E1 to E8)

\begin{tabular}{lcccccc}
\hline & \multicolumn{2}{c}{ Conventional } & \multicolumn{2}{c}{ Islamic } & & \\
Variables & M & $S D$ & M & $S D$ & Mean difference & p-value \\
\hline E17 & 0.490 & 1.189 & 0.466 & 0.926 & 2.684 & 0.458 \\
Averages & 0.490 & & 0.466 & & -0.025 & *** \\
Grand average & 0.228 & & 1.328 & & 0.274 & *****
\end{tabular}

Notes: ${ }^{* * * *} \mathrm{CBs}$ perform slightly better in terms of credit risk; $* * * * *$ On average, IBs in Pakistan perform better than CBs after financial crisis

Table XIV.

Descriptive analysis of $\mathrm{CBs}$ vs IBs - CRM

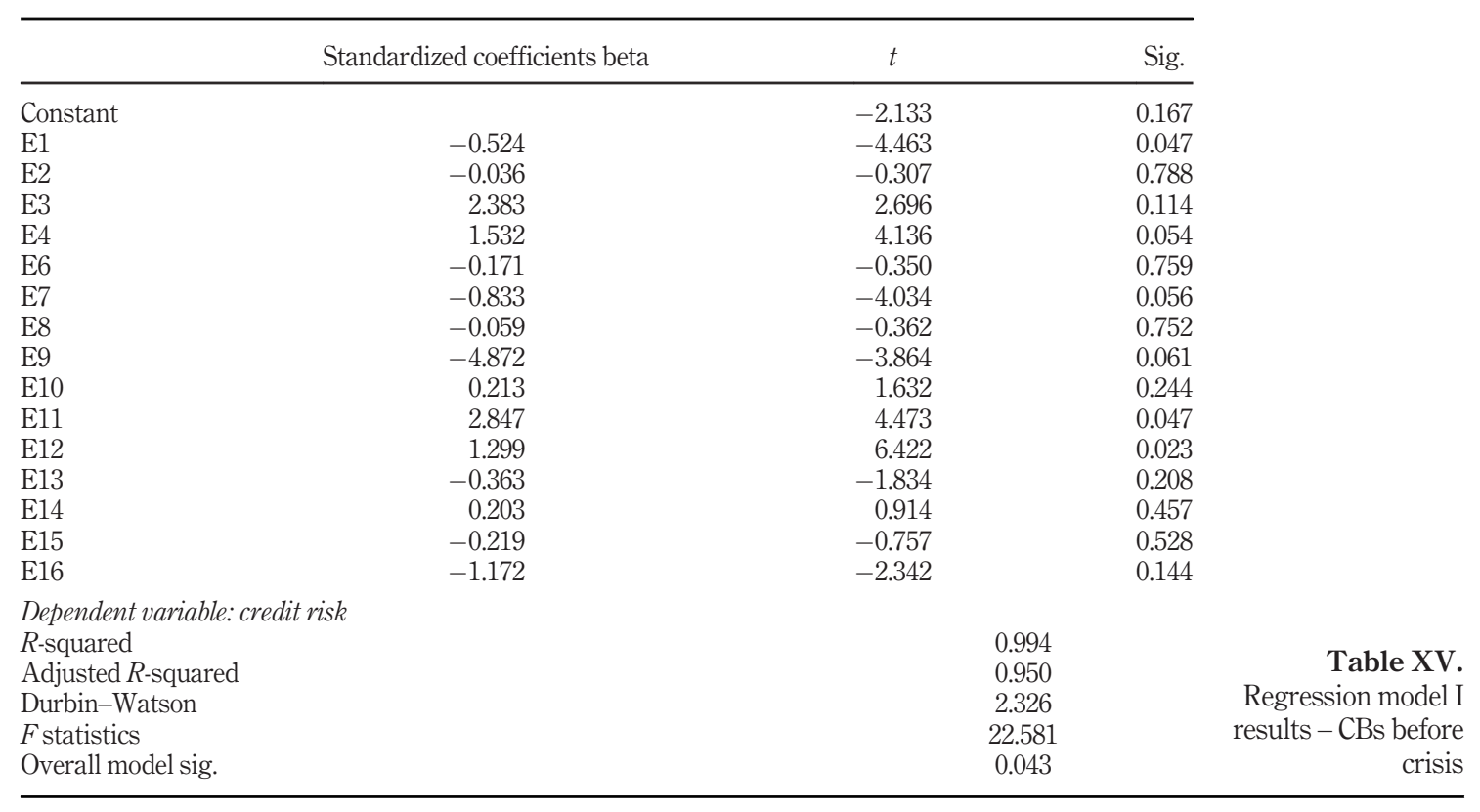




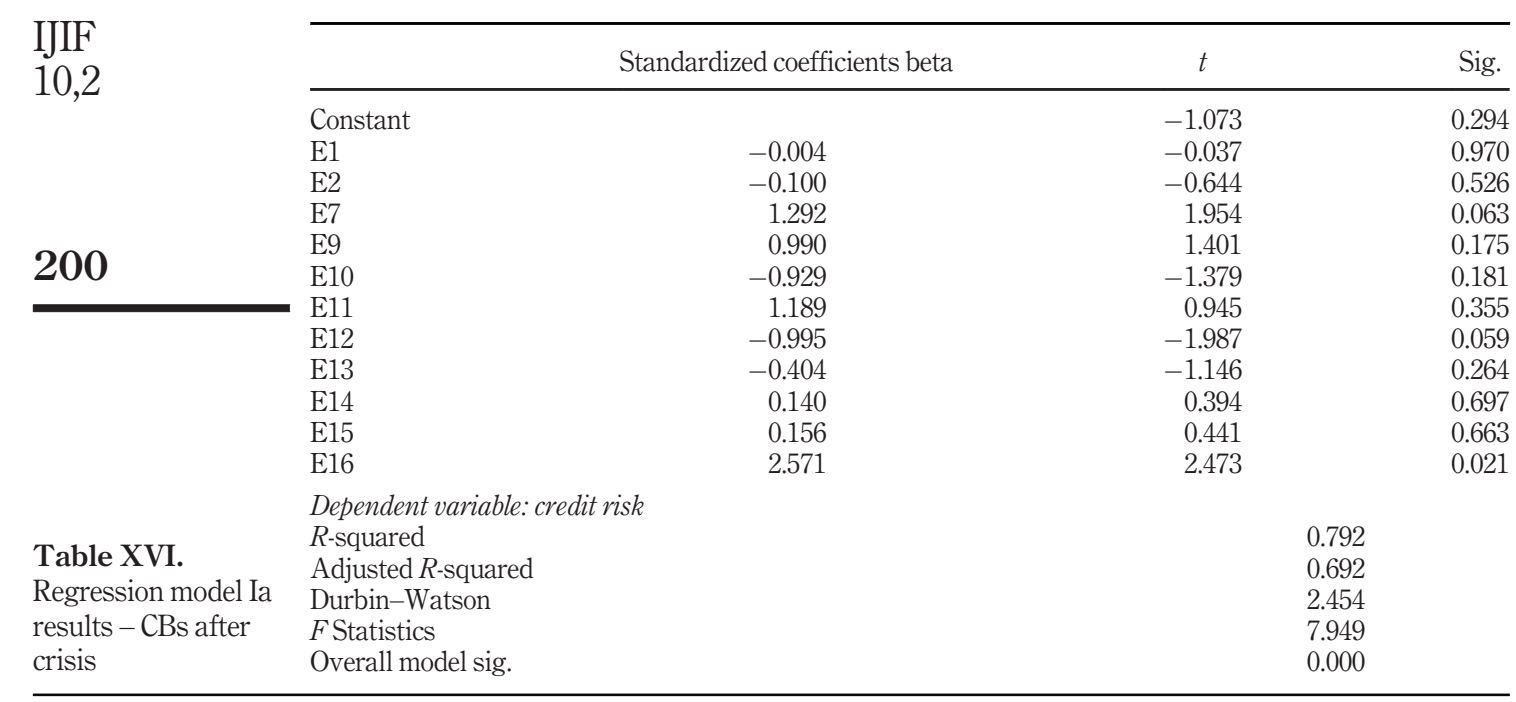

and $\mathrm{AQ}$ (E9 to E16), and their impact on dependent variable CRM has been observed. The regression results for CBs before the 2008 crisis, as given in Table XV, show a healthy $R^{2}$ value of 99 per cent and adjusted $R^{2}$ value of 95 per cent, which is a representation that change in independent variables LQ and AQ causes 95 per cent change in the dependent variable. The Durbin-Watson value of 2.326 shows that there is no autocorrelation among the variables.

Similarly, the regression results for CBs after the 2008 crisis, as depicted in Table XVI, show an $R^{2}$ value of 79 per cent and adjusted $R^{2}$ value of 69 per cent, which is a representation that change in independent variables LQ and AQ causes 69 per cent change in the dependent variable. The Durbin-Watson value of 2.454 shows that there is no autocorrelation among the variables. The regression model proves significant even if the ratios measuring the independent variables were calculated individually for the CBs.

In Tables XVII and XVIII, regression analysis has been run using individual ratios that collectively construct the independent variables LQ (E1 to E8) and AQ (E9 to E16), and their impact on dependent variable CRM has been observed. The regression results for IBs before the 2008 financial crisis (as per Table XVII) shows a healthy $R^{2}$ value of 99.9 per cent and an adjusted $R^{2}$ value of 99.3 per cent, which is a representation that change in independent variables LQ and AQ causes 99.3 per cent change in the dependent variable CRM. A Durbin-Watson value of 3.211 shows that there is no autocorrelation among the variables.

Similarly, the regression results for IBs after the 2008 crisis (as per Table XVIII) show an $R^{2}$ value of 67.6 per cent and an adjusted $R^{2}$ value of 49.7 per cent, which is a representation that change in independent variables LQ and AQ causes 49.7 per cent change in the dependent variable. A Durbin-Watson value of 1.741 shows that there is no autocorrelation among the variables. The regression model in the case of IBs proves significant even if the ratios measuring the independent variables were run individually.

Tables XIX and XX, respectively, present the results of the regression model III for CBs and model IV for IBs in terms of overall average performance of banks over the 13-year period. Here, the average of eight ratios (E1 to E8) has been used to measure LQ, and an average of another eight ratios (E9 to E16) has been used to measure $\mathrm{AQ}$, and their impact has been observed on the dependent variable CRM using the 13-years data. The results of 


\begin{tabular}{lcrrrr}
\hline & Standardized coefficients beta & $t$ & Sig. & $\begin{array}{r}\text { Credit risk } \\
\text { management }\end{array}$ \\
\hline Constant & & -0.081 & 0.943 & \\
E1 & 0.132 & 0.251 & 0.826 & \\
E2 & 0.890 & 3.169 & 0.087 & \\
E4 & 0.776 & 2.712 & 0.113 & \\
E5 & -0.115 & -0.214 & 0.851 & \\
E6 & 2.864 & 12.244 & 0.007 & \\
E7 & 0.189 & 0.338 & 0.768 & \\
E8 & 0.165 & 0.824 & 0.497 & \\
E10 & 1.249 & 4.956 & 0.038 & \\
E11 & -0.906 & -3.216 & 0.085 & \\
E13 & -0.218 & -0.736 & & 0.538 & \\
E14 & -0.375 & -1.579 & & 0.255 & \\
E15 & -1.277 & -2.240 & & 0.154 & \\
E16 & -2.670 & -13.276 & & 0.006 & \\
Dependent variable: credit risk & & & 0.999 & & Table XVII. \\
$R$-squared & & & 0.993 & & Regression model II \\
Adjusted $R$-squared & & & 3.211 & & results - IBs before \\
Durbin-Watson & & & 0.061 & & crisis \\
$F$ Statistics & & & & &
\end{tabular}

\begin{tabular}{|c|c|c|c|c|c|}
\hline & Standardized coefficients beta & \multicolumn{2}{|l|}{$t$} & \multicolumn{2}{|l|}{ Sig. } \\
\hline \multicolumn{2}{|l|}{ Constant } & 0.835 & & 0.414 & \\
\hline E1 & 0.033 & 0.235 & & 0.816 & \\
\hline E2 & -0.032 & -0.182 & & 0.858 & \\
\hline E7 & 0.127 & 0.227 & & 0.823 & \\
\hline E9 & 1.233 & 1.134 & & 0.270 & \\
\hline E10 & -0.117 & -0.319 & & 0.753 & \\
\hline E11 & -0.008 & -0.032 & & 0.975 & \\
\hline E12 & -1.368 & -1.401 & & 0.177 & \\
\hline E13 & 0.560 & 0.887 & & 0.385 & \\
\hline E14 & 0.098 & 0.689 & & 0.499 & \\
\hline E15 & -0.934 & -1.276 & & 0.217 & \\
\hline E16 & 1.403 & 1.741 & & 0.097 & \\
\hline \multicolumn{6}{|c|}{ Dependent variable: credit risk } \\
\hline \multicolumn{2}{|c|}{$\begin{array}{l}R \text {-squared } \\
\text { Adiusted } R \text {-squared }\end{array}$} & & 0.676 & & \\
\hline \multicolumn{2}{|c|}{$\begin{array}{l}\text { Adjusted } R \text {-squared } \\
\text { Durbin-Watson }\end{array}$} & & 0.497 & & $\begin{array}{l}\text { I able XVIII. } \\
\text { Regression model IIa }\end{array}$ \\
\hline \multirow{2}{*}{\multicolumn{2}{|c|}{$\begin{array}{l}\text { Durbin-Watson } \\
F \text { statistics }\end{array}$}} & & 1.741 & & $\begin{array}{l}\text { Regression model lla } \\
\text { results - IBs after }\end{array}$ \\
\hline \multirow{2}{*}{\multicolumn{2}{|c|}{$\begin{array}{l}F \text { statistics } \\
\text { Overall model sig. }\end{array}$}} & & 3.789 & & results - IBs after \\
\hline & & & 0.005 & & crisis \\
\hline
\end{tabular}

CBs in model III show that there exists a significant and positive relationship between the independent variables LQ, AQ and the dependent variable CRM.

The Durbin-Watson test has a value of 1.595 for the CBs regression model, which shows that there is no autocorrelation between the variables. Field (2009) highlighted that values under 1 or above 3 are definitely a cause for concern. The $R^{2}$ value is 22.2 per cent for $\mathrm{CBs}$, which represents the change that occurred in CBs' CRM due to changes in LQ and AQ. This shows that both AQ and LQ cause significant changes in CRM in the case of CBs, so 
these two variables must be considered while making CRM policies or managing CRM. The CBs should have absolute understanding and clear policies for managing their credit portfolios, acquiring new loan business and when giving out loans; otherwise, credit risk may arise. The funds generated through inter-bank borrowing and customer deposits should be properly utilized for enhancing the loan portfolio and asset creation so that credit risk does not arise due to an increase in NPL.

On the other hand, Table XIX shows the results of the regression model IV for the IBs. The results show that the independent variable AQ has a negative relationship with CRM, whereas the independent variable LQ has a significant and positive impact on CRM. The $R^{2}$ value is 63.5 per cent, which depicts the variations in the independent variables $L Q$ and $A Q$ that caused changes in the dependent variable CRM. The Durbin-Watson test has a value of 1.585 for the IBs regression model, which shows that autocorrelation does not exist between the variables. The results of the regression model reveal that LQ has a significant and positive impact on CRM for IBs. Accordingly, policymakers at IBs should carefully analyze $\mathrm{LQ}$, while $\mathrm{AQ}$ should also be given due preference.

\section{Conclusion and recommendations}

This research work attempts to analyze CRM performance, taking into account a comparative analysis of CBs and IBs operating in Pakistan. The results of the study reveal that LQ does affect CRM significantly and positively for both CBs and IBs. It is also derived from the results that the independent variable $\mathrm{AQ}$ has a negative impact on CRM in the IBs under study, whereas it has a significant and positive impact on CRM in the CBs. LQ, being significantly important, should always be emphasized while developing a loan portfolio to

\begin{tabular}{lcrc}
\hline & Standardized coefficients beta & $t$ & Sig. \\
\hline Constant & & 0.752 & 0.456 \\
AQ & 0.156 & -2.435 & 0.019 \\
LQ & 0.484 & 3.190 & 0.002 \\
Dependent variable: credit risk & & & \\
$R$-squared & & 0.222 & \\
Adjusted $R$-squared & & 0.191 & \\
Durbin-Watson & 1.595 & \\
$F$ statistics & 7.129 & \\
Overall model sig. & & 0.002 & \\
\hline
\end{tabular}

Table XIX.

Regression model III results $-\mathrm{CBs}$

\begin{tabular}{lcrr}
\hline & Standardized coefficients beta & \multicolumn{1}{c}{ Sig. } \\
\hline Constant & & 2.504 & 0.016 \\
$\mathrm{AQ}$ & -0.038 & -0.410 & 0.684 \\
$\mathrm{LQ}$ & 0.797 & 8.548 & 0.000 \\
Dependent variable: credit risk & & & \\
$R$-squared & 0.635 & \\
Adjusted $R$-squared & 0.618 & \\
Durbin-Watson & 1.585 & \\
$F$ statistics & 36.584 & \\
Overall model sig. & 0.000 & \\
\hline
\end{tabular}


avoid NPL and loan defaults in the future. This will reduce credit risk, thereby exhibiting improved CRM practices. For robust comparison, the impact of 16 ratios measuring LQ and $\mathrm{AQ}$ have also been individually checked through regression analysis using a dummy variable for the 2008 financial crisis to see their impact on CRM. It is pertinent to note that the regression model still remains significant.

On the basis of the results obtained, it is recommended that both CBs and IBs should carefully devise their credit management policies in terms of utilization of funds acquired through deposits and interbank liabilities to disburse loans and make investments. It is vital to consider the important factors of $L Q$ and $A Q$ while making policies regarding CRM. Interbank liabilities should only be generated in case of urgency when huge withdrawals take place or any other economic/financial shock hits the banking industry in order to avoid default. The proportion of liquid assets must be enlarged in the banks' balance sheets, both for IBs and CBs, so that the asset portfolio may be strengthened.

The descriptive statistical analysis results reveal that IBs showing higher variables' mean average value of ratios (1.328) are performing better than CBs $(0.228)$ in terms of LQ and AQ, and thereby managing credit risk. The descriptive analysis carried out using a dummy variable to account for the 2008 financial crisis also shows that IBs have either been showing a better performance or their performance has been improving significantly.

The research findings in this paper are supported by the research conducted by Abdel Megeid (2017) on the Egyptian banking industry. Although there is still a difference in the market size catered by IBs and CBs - as CBs comparatively have a huge customer base, whereas IBs are a developing phenomenon - the results show that IBs have performed better within given circumstances than CBs in terms of CRM. The CBs should also strive to acquire new markets to develop a sound asset portfolio base like IBs and should also invest in asset-backed advances/loans along with the already existing interest-based loan portfolio.

The following recommendations can be made on the basis of this study:

- The results of the study will be helpful for banks operating in Pakistan to carefully devise CRM policies keeping in view the impact of LQ and AQ on CRM.

- The study highlights that CRM of IBs after the 2008 financial crisis needs certain improvements to better compete with CBs.

- The study provides an insight on the better performance of IBs with respect to CRM. This may encourage CBs to look into the prospects of developing Islamic banking services.

- The study highlights the importance of having trained personnel to undertake proper CRM and reduce credit risk.

In general, it is inferred from the study that CRM is a vital phenomenon for banking operations and that optimum standards for developing the credit portfolio should be established. This should be supported by an additional cushion to face any untoward situation like increase in defaults/NPLs or economic/industrial depression. This study can also assist banks regarding their future development of CRM policies and practices and the role of important variables like AQ and LQ affecting CRM. It also paves the way for similar studies in the future that keep in view various variables like liability and equity structures of the banks and the different risks involved therein. 


\section{References}

Abdel Megeid, N.S. (2017), "Liquidity risk management: conventional versus Islamic banking system in Egypt”, Journal of Islamic Accounting and Business Research, Vol. 8 No. 1, pp. 100-128.

Abdul Manab, N., Theng, N.Y. and Md-Rus, R. (2015), "The determinants of credit risk in Malaysia”, Procedia-Social and Behavioral Sciences, Vol. 172 No. 1, pp. 301-308.

Abiola, I. and Olausi, A.S. (2014), "The impact of credit risk management on the commercial banks performance in Nigeria", International Journal of Management and Sustainability, Vol. 3 No. 5 , pp. 295-306.

Agoraki, M.E.K., Delis, M.D. and Pasiouras, F. (2011), "Regulations, competition and bank risk-taking in transition countries", Journal of Financial Stability, Vol. 7 No. 1, pp. 38-48.

Ahmad, N.H. and Ahmad, S.N. (2004), "Key factors influencing credit risk of Islamic bank: a Malaysian case", The Journal of Muamalat and Islamic Finance Research, Vol. 1 No. 1, pp. 1-10.

Alhassan, A.L., Kyereboah-Coleman, A. and Andoh, C. (2014), "Asset quality in a crisis period: an empirical examination of Ghanaian banks", Review of Development Finance, Vol. 4 No. 1, pp. 50-62.

Altıntaş, M.A. (2012), "Kredi kayıplarının makroekonomik değişkenlere dayalı olarak tahmini ve stres testleri”, Türk bankacılık sektörü için ekonometrik bir yaklaşım, Türkiye Bankalar Birliği, Istanbul.

Bekhet, H.A. and Eletter, S.F.K. (2014), "Credit risk assessment model for Jordanian commercial banks: neural scoring approach", Review of Development Finance, Vol. 4 No. 1, pp. 20-28.

Berger, A.N. and Deyoung, R. (1997), "Problem loans and cost efficiency in commercial banks", Journal of Banking and Finance, Vol. 21 No. 6, pp. 849-870.

Bessis, J. (2011), "Liquidity risk: a risk left to be tamed", Journal of Risk Management in Financial Institutions, Vol. 4 No. 2, pp. 108-111.

Demirgüç-Kunt, A. and Huizinga, H. (1999), "Determinants of commercial bank interest margins and profitability: some international evidence", The World Bank Economic Review, Vol. 13 No. 2, pp. 379-408.

Diamond, D.W. (1991), "Monitoring and reputation: the choice between bank loans and directly placed debt", Journal of Political Economy, Vol. 99 No. 4, pp. 689-721.

Doğan, M. (2013), "Comparison of financial performances of domestic and foreign banks: the case of Turkey”, International Journal of Business and Social Science, Vol. 4 No. 1, pp. 233-240.

Duffie, D. and Singleton, K.J. (1999), "Modeling term structures of defaultable bonds", Review of Financial Studies, Vol. 12 No. 4, pp. 687-720.

Field, A. (2009), Discovering Statistics Using IBM SPSS Statistics, Sage Publications, London.

Gaganis, C., Pasiouras, F. and Zopounidis, C. (2006), "A multicriteria decision framework for measuring banks' soundness around the world", Journal of Multi-Criteria Decision Analysis, Vol. 14 Nos 1/3, pp. 103-111.

How, J.C.Y., Karim, M.A. and Verhoeven, P. (2005), "Islamic financing and bank risks: the case of Malaysia", Thunderbird International Business Review, Vol. 47 No. 1, pp. 75-94.

Iannotta, G., Nocera, G. and Sironi, A. (2007), "Ownership structure, risk and performance in the european banking industry", Journal of Banking and Finance, Vol. 31 No. 7, pp. 2127-2149.

Jorion, P. and GARP (2009), Financial Risk Manager Handbook, John Wiley and Sons, NJ, New York, NY.

Kaplan, S.N. and Stein, J.C. (1993), "The evolution of buyout pricing and financial structure (or, what went wrong) in the 1980s", Journal of Applied Corporate Finance, Vol. 6 No. 1, pp. 72-88.

Knight, F.H. (1964), Risk, Uncertainty and Profit, Augustus, M. Kelley, Bookseller, New York, NY.

Kopecky, K.J. and Vanhoose, D. (2006), "Capital regulation, heterogeneous monitoring costs, and aggregate loan quality”, Journal of Banking and Finance, Vol. 30 No. 8, pp. 2235-2255. 
Louzis, D.P., Vouldis, A.T. and Metaxas, V.L. (2012), "Macroeconomic and bank-specific determinants of non-performing loans in Greece: a comparative study of mortgage, business and consumer loan portfolios", Journal of Banking and Finance, Vol. 36 No. 4, pp. 1012-1027.

Love, I. and Ariss, R.T. (2014), "Macro-financial linkages in Egypt: a panel analysis of economic shocks and loan portfolio quality", Journal of International Financial Markets Institutions and Money, Vol. 28 No. 1, pp. 158-181.

Nkusu, M. (2011), "Nonperforming loans and macrofinancial vulnerabilities in advanced economies", IMF Working Paper, WP/11/161, International Monetary Fund, Washington, DC, July.

Öker, A. (2007), "Ticari bankalarda kredi ve kredi riski yönetimi-bir uygulama”, Doctoroal thesis, Marmara Üniversitesi Sosyal Bilimler Enstitüsü Yayınlanmamış Doktora Tezi, Istanbul.

Ongore, V.O. and Kusa, G.B. (2013), "Determinants of financial performance of commercial banks in Kenya", International Journal of Economics and Financial Issues, Vol. 3 No. 1, pp. 122-132.

Palubinskas, G.T. and Stough, R.R. (1999), "Common causes of bank failures in post-communist countries", The Institute of Public Policy, George Mason University, available at: http://citeseerx. ist.psu.edu/viewdoc/download?doi=10.1.1.195.783\&rep=rep1\&type=pdf (accessed 11 September 2018).

Saif-Alyousf, A.Y.H., Saha, A. and Md-Rus, R. (2017), "Profitability of saudi commercial banks: a comparative evaluation between domestic and foreign banks using Capital adequacy, asset quality, management quality, earning ability and liquidity parameters", International Journal of Economics and Financial Issues, Vol. 7 No. 2, pp. 477-484.

Shehzad, C.T. and De Haan, J. (2013), "Was the 2007 crisis really a global banking crisis?", The North American Journal of Economics and Finance, Vol. 24 No. 1, pp. 113-124.

Tektas, A., Nur Ozkan-Gunay, E. and Gunay, G. (2005), "Asset and liability management in financial crisis”, The Journal of Risk Finance, Vol. 6 No. 2, pp. 135-149.

Tsaig, Y., Levy, A. and Wang, Y. (2010), "Analyzing the impact of credit migration in a portfolio setting”, Moody's Analytics, available at: www.moodysanalytics.com/-/media/whitepaper/before-2011/ 2010-17-9-analyzing-the-impact-of-credit-migration-in-a-portfolio-setting.pdf (accessed 9 September 2018).

Yurdakul, F. (2014), "Macroeconomic modelling of credit risk for banks", Procedia-Social and Behavioral Sciences, Vol. 109 No. 3, pp. 784-793.

\section{Further reading}

Cantor, R. (2001), "Moody's investors service response to the consultative paper issued by the basel committee on bank supervision 'a new capital adequacy framework", Journal of Banking and Finance, Vol. 25 No. 1, pp. 171-185.

\section{About the authors}

Hassan Akram works as an AVP-Branch Manager at the National Bank of Pakistan, Lahore, Pakistan. He has 11 years of post-qualification professional banking experience along with educational qualifications of MBA and MS.

Khalil ur Rahman works as Senior Research Officer at Al-Huda Center of Islamic Banking and Economics, Pakistan. He has 12 years of post-qualification professional Islamic banking and Islamic finance research experience along with educational qualifications of MBA and MPhil. Khalil ur Rahman is the corresponding author and can be contacted at: khalil.research@gmail.com

For instructions on how to order reprints of this article, please visit our website:

www.emeraldgrouppublishing.com/licensing/reprints.htm

Or contact us for further details: permissions@emeraldinsight.com 